\title{
Preface to the First Edition
}

When he was merely a persecuted priest, Haitian President JeanBertrand Aristide wrote of the "unending goodness" of poor Haitians "in unimportant matters as well as [in] the gravest issues." In a setting of near-total illiteracy, it is difficult to claim that a scholarly book could be a grave issue. I must therefore thank my Haitian hosts for helping me to attend to what could only seem to be a relatively unimportant matter-a book written in English. That a non-Haitian physician/anthropologist would find himself writing a book about AIDS in Haiti is largely an accident of what might be clumsily termed historically produced social arrangements. The evolution of these arrangements and their relation to AIDS are subjects treated in considerable detail in this study, which attempts to examine current ethnographic and epidemiologic data from a historical perspective. This approach has generated some disagreement about the place of historical materials in a consideration of a thoroughly modern epidemic.

During the editorial process, the non-Haitian readers of this book felt that the history section, Part IV, could be radically abridged or cut out altogether. Haitian readers felt these chapters should stay. In the end, preserving the historical chapters became something of a sticking point, as a central thesis of the book is that the world pandemic of AIDS and social responses to it have been patterned by the social arrangements described in the historical chapters. But there was a second, more important reason for keeping these chapters: if there has been, among my informants, any consensus about the meaning of AIDS, it 
has been that the biological and social effects of this new scourge have to be examined in the light of past misfortunes. In many ways, then, this study is largely a juxtaposition of a recent and still unfolding process-the AIDS epidemic-and a sympathetic reading of the historical trajectory of the Haitian people.

A second prefatory note concerns Haiti and the origins of AIDS. As a U.S.-trained physician, it is clear to me that, even today, many health professionals have distorted views about AIDS and Haiti. These distortions are even more grotesque among the lay public, as many North Americans still believe that AIDS came to the United States from Haiti, and not vice versa. My rebuttal to this frequently encountered view about the provenance of HIV, which is informed by clinical and historical evidence, may come as unwelcome news to some. The virus itself is unwelcome, all the more so for being mysterious in its origin. The reader will, I hope, understand that my purpose in charting the social as well as biological movements of this virus is not in the least to add to the cycles of accusation and counteraccusation chronicled here. It is nonetheless important to set the record straight by correcting widely held misperceptions about AIDS and Haitians. What data exist do not support the thesis that HIV reached North America from Haiti.

Questions will arise, inevitably, about the methodologies underpinning this study. The analysis presented here was based on years of participant-observation, the central methodology of ethnographic fieldwork. Not all readers will be interested in the methodological and ethical questions posed by fieldwork conducted among the very poor and in the midst of an epidemic, and I have to a large extent relegated such discussion to journal articles and book chapters (for example, Farmer 1990a, 1991a). Other major methodological issues discussed concern the means by which it is possible, through serial interviews, to trace emerging meanings of AIDS (Farmer 1990c). Broader statements about AIDS and the constitution of an anthropology of suffering have also been elaborated (Farmer 1988a, Farmer and Kleinman 1989), as has an extended discussion of the significance of AIDS vis-à-vis the subfield of medical anthropology (Farmer and Good 1991). Further, as physician-anthropologists concerned with the prevention and treatment of infectious disease, we have discussed these ethnographic data in the context of pragmatic efforts to prevent HIV transmission (Farmer and Kim 1991; Farmer, Robin, Ramilus, and Kim 1991).

Finally, I must acknowledge the debts accrued in the course of conducting this research and writing this book. I risk a hackneyed gesture 
by beginning a long list of acknowledgments with a solemn thank-you to the people of "Do Kay." It is difficult to find words to express the admiration I feel for those who have suffered with dignity and still remain warm to one who represents, after all, the source of no small amount of their travail. Formal acknowledgment is due the MacArthur Foundation, whose generous support made it possible for me to pursue training in both medicine and anthropology. I am also grateful to Harvard Medical School, which twice subventioned my research in rural Haiti. Less formal, more affectionate thanks to Fritz and Yolande Lafontant, who encouraged me when scholarly questions seemed somehow unimportant. Quite simply, this book would not have been written without them. Similarly, Thomas White not only supported Projè Veye Sante, the preventive health project in which I worked, but also offered moral support and technical assistance.

Peggy and Jennifer Farmer and, especially, Ophelia Dahl shared some of these fieldwork experiences with me. Ophelia helped me to understand a great deal about Haiti and I will always be grateful to her. Jean François and Lernéus Joseph have spent years working on Projè Veye Sante, and have themselves become proficient ethnographic fieldworkers. I thank, too, the many others who work on Projè Veye Sante. I will never forget our three coworkers felled by preventable or treatable diseases: Acéphie Lamontagne, Michelet Joseph, and Marie-Ange "Ti Tap" Joseph.

Several Haitian physicians have my respect and admiration. For their long years of fraternity and hope, I thank Ramilus St. Luc, Simon Robin, Ernst Calixte, and Maxi Raymonville. I am grateful to MarieMarcelle Deschamps and Jean Pape, who have contributed to the international scientific community's understanding of AIDS. Even better, they have alleviated, with few resources and under poor conditions, the suffering of hundreds of their compatriots with AIDS.

More broad-ranging counsel was given by Steven Nachman and Haun Saussy. I am fortunate indeed to have their advice, and the rigor of their scholarship stands as a challenge to those of us who become sloppy when the heat is on. Allan Brandt, Leon Eisenberg, John Hines, Mariette Murphy, Jeffrey Parsonnet, Pauline Peters, Camille K. Rogers, Ricardo Sanchez, and Madeleine Wilson have provided insightful commentary on material presented here. Stylistic advice was given by Jennifer Farmer and, especially, Carla Fujimoto and Jenny Hall. Stanley Holwitz of the University of California Press encouraged me to transform my doctoral dissertation into a book. 
Several Haitianists or Caribbeanists have commented on the ethnographic or historical portions of this book. Catherine Maternowska has been a supportive yet critical reader for years. Bicultural Ruth Berggren helped me to decipher key passages from difficult interviews, as did Jenny Hall. Rosemarie Chierici, manman poul, attempted to remove any errors that might embarrass me. Laennec Hurbon and Orlando Patterson offered encouragement and advice. I am also grateful for the insights provided by the members of the American Anthropological Association's Task Force on AIDS, most notably Shirley Lindenbaum, and to the AIDS and Anthropology Research Group.

It is an honor to acknowledge a great debt to Arthur Kleinman. His students know him as the principal architect of a community of scholars that take seriously the study of the social construction of illness-without losing sight of the sufferers. I am also indebted to Leon Eisenberg and members of the Department of Social Medicine at Harvard Medical School, where Kleinman and Eisenberg have created a haven for an eclectic group of physicians and social scientists. Byron Good and MaryJo DelVecchio Good are in a category apart. They have been for many of us exemplars of scholarship who count as their family the intellectual community they have helped to build. Sally Falk Moore accorded me encouragement when it was much needed, and also lent a certain theoretical legitimacy to a fieldwork style that was mandated as much by medical school as by intellectual concerns. I have also benefitted enormously from the friendship of Joan Gillespie and Rosemarie Bernard. Most of all, I thank Jim Yong Kim, who shares a concern not only for the theoretical issues posed by anthropology and medicine, but also for the moral dilemmas that face any North American academic who would venture into the "Third World." These are the members of my intellectual community.

I could not speak of community without reference to Roxbury, Massachusetts, and Do Kay, the two settings in which I have, with brief exception, spent the last decade. Jack, Mary, Katherine, Lucy, and Carola in the States, and Papa Frico, Mamito, Flore, Jeje, Ram, Simon, Poteau, Thérèse, Paulette, Marcelin, and Carnest in Haiti have made living in two places a feasible proposition. I now look to Tom, Jim, Jenny, Cathy, Todd, Guitèle, Jody, and others from Partners in Health, who have been in both places, to help me to live up to the exacting standards set by my own family. This book is dedicated to Virginia Farmer, to Katy, Jim, Jeff, Jen, Peggy, and, especially, to the memory of our father. 